\title{
Biomass of autotrophic picoplankton in subtropical coastal lagoons: Is it relevant?
}

\author{
Leticia Vidal ${ }^{1, *}$, Lorena Rodríguez-Gallego ${ }^{1}$, Daniel Conde ${ }^{1}$, Wilner Martínez-López ${ }^{2}$ and \\ Sylvia Bonilla ${ }^{1}$
}

1 Sección Limnología, Facultad de Ciencias, Universidad de la República, Iguá 4225, CP 11400, Montevideo, Uruguay.

2 Servicio de Clasificación Celular y Citometría de Flujo, Instituto de Investigaciones Biológicas Clemente Estable, Av. Italia 3318, CP 11600, Montevideo, Uruguay.

*Corresponding author: leti@fcien.edu.uy

\begin{abstract}
Biomass of autotrophic picoplankton in subtropical coastal lagoons: Is it relevant?

The importance of the autotrophic picoplankton (APP, $<2 \mu \mathrm{m}$ ) to the primary productivity of coastal lagoons has been recently recognized. However, the role of these organisms in highly dynamic systems such as coastal lagoons is not well understood. The Atlantic coast of Uruguay $\left(34^{\circ} 20^{\prime}-34^{\circ} 54^{\prime} \mathrm{S} ; 53^{\circ} 55^{\prime}-55^{\circ} 00^{\prime} \mathrm{W}\right)$ is characterized by the presence of a series of subtropical coastal lagoons (depth: $0.2-2.0 \mathrm{~m}$ ) that differ in the dynamics of the interaction with the ocean, their salinity, morphometry, and anthropogenic impact. The relative contribution of eukaryotic and prokaryotic APP to the total phytoplankton biomass in five coastal lagoons was determined and its relation to the abiotic factors was analyzed. Phytoplankton was identified and quantified using flow cytometry and optical microscopy. Chlorophyll $a(\mathrm{Chl}-a)$ concentration was determined through seasonal samplings. The conductivity varied from limnic $(<0.3 \mathrm{mS} / \mathrm{cm})$ to brackish conditions $(36.6 \mathrm{mS} / \mathrm{cm})$. The concentration of dissolved inorganic nitrogen and the DIN/SRP atomic ratio were generally low (ranging from undetectable to $107.2 \mu \mathrm{g} / \mathrm{l}$, and from $<1$ to $52.3 \mu \mathrm{g} / \mathrm{l}$, respectively). The total Chl- $a$ ranged from 0.7 to $18.3 \mu \mathrm{g} / \mathrm{l}$ from which the picoplanktonic fraction represented from 4.2 to $96.6 \%$. In general, the Chl- $a$ picoplanktonic fraction was negatively correlated with the total concentration of Chl- $a$. The cytometric analysis of the picoplankton allowed the identification of six ataxonomic groups, indicating that picoeukaryote groups were dominant throughout the study, although picocyanobacteria were occasionally important. It was found that suspended solids and dissolved inorganic nitrogen were the most important factors related to the APP Chl- $a$ contribution.
\end{abstract}

Key words: Picoeukaryotes, picocyanobacteria, phytoplankton, flow cytometry, nutrients.

\section{RESUMEN}

La biomasa del picoplancton autótrofo en lagunas costeras subtropicales: es relevante?

La importancia del picoplancton autótrofo $(P P A,<2 \mu \mathrm{m})$ para la productividad primaria de las lagunas costeras ha sido reconocida recientemente. Sin embargo, el rol de estos organismos en sistemas altamente dinámicos como lagunas costeras es aún poco comprendido. La costa atlántica de Uruguay $\left(34^{\circ} 20^{\prime}-34^{\circ} 54^{\prime} \mathrm{S}\right.$; $\left.53^{\circ} 55^{\prime}-55^{\circ} 00^{\prime} \mathrm{W}\right)$ se caracteriza por la presencia de una serie de lagunas costeras subtropicales (profundidad: 0.2-2.0 m) que difieren en su dinámica de interacción con el océano, salinidad, morfometría e impacto antrópico. Se determinó la contribución relativa del PPA a la biomasa fitoplanctónica total en cinco de estas lagunas costeras y se analizó su relación con los factores abióticos. Se identificó y cuantificó el fitoplancton mediante citometría de flujo y microscopía óptica y se determinó la concentración de clorofila a (Clo-a) en base a muestreos estacionales. La conductividad varió desde condiciones límnicas $(<0.3 \mathrm{mS} / \mathrm{cm})$ a salobres $(36.6 \mathrm{mS} / \mathrm{cm})$. La concentración de nitrógeno inorgánico disuelto (NID) y su relación atómica con el fósforo reactivo soluble (NID/PRS) generalmente presentaron valores bajos (de indetectable a $107.2 \mu \mathrm{g} / \mathrm{l}, y<1$ a $52.3 \mu \mathrm{g} / \mathrm{l}$ respectivamente). La Clo-a total varió entre 0.7 y $18.3 \mu \mathrm{g} / \mathrm{l}$, de la cual la fracción picoplanctónica representó entre 4.2 y $96.6 \%$. En general, la fracción picoplanctónica de Clo-a se correlacionó negativamente con la concentración total de Clo-a. El análisis del PPA mediante citometría de flujo permitió identificar al menos seis grupos ataxonómicos, indicando que los grupos picoeucariotas fueron dominantes durante todo el estudio, aunque las picocianobacterias fueron ocasionalmente importantes. Los sólidos en suspensión y la concentración de NID fueron los factores más importantes asociados a la contribución de la Clo-a del PPA.

Palabras clave: Picoeucariotas, picocianobacterias, fitoplancton, citometría de flujo, nutrientes. 


\section{INTRODUCTION}

Autotrophic picoplankton (APP, $<2 \mu \mathrm{m}$ ) is the main contributor to phytoplankton biomass and primary production in open oceans (Worden et al., 2004). Ever since the discovery of different phylogenetic groups among picophytoplankton, the diversity of this fraction has received more attention in coastal (Hall \& Vincent, 1990; Díez et $a l ., 2001)$ and freshwater environments (Callieri $\&$ Stockner, 2002). These small phototrophic organisms, both prokaryotic and eukaryotic, constitute an essential component of microbial food webs, playing a significant role in the major biogeochemical cycles of coastal waters (Courties et al., 1994; Li et al., 2001; Bec et al., 2004; Not et al., 2004; Rodríguez et al., 2005).

The dominance of APP is generally associated with oligotrophic systems, where primary production is mainly sustained by nutrient regeneration through the microbial loop (Stockner, 1991; Chisholm, 1992). Under these conditions, these small sized organisms have competitive advantages in relation to bigger cells (Suttle et al., 1987; 1988). An inverse trend between the relative contribution of APP to total autotrophic carbon fixation and the trophic state is accepted (Petersen, 1991; Stockner, 1991), although Stockner et al. (2000) pointed out that this trend is highly variable and difficult to predict.

Salinity is another important factor that influences phytoplankton composition and growth in coastal ecosystems (Day et al., 1989). Investigations carried out in systems with salinity gradients showed that picophytoplankton abundance presented a bimodal distribution, with peaks under both extremely low and high salinity conditions (Estrada et al., 2004).

The term coastal lagoon covers diverse aquatic ecosystems influenced by both marine and terrestrial environments (Barnes, 1980; Knoppers, 1994). The interaction of hydrological forces, like horizontal flow, mixing of the water column, water exchange with the ocean, and residence times, modulates the functioning of these ecosystems. The connection with the ocean determines large variations in the physical and chemical conditions like salinity, turbi- dity, and nutrient concentration and consequently it also determines large variations in phytoplankton biomass, dominant size fractions, taxonomic groups, and life strategies (Barnes, 1980; Mukai, 1987; Kjerfve, 1994; Macedo et al., 2001, Badylak \& Phlips, 2004; Bonilla et al., 2005; Odebrecht et al., 2005).

On the Atlantic coast of Uruguay there are a series of subtropical coastal lagoons located in a MaB/UNESCO Biosphere World Reserve, which differ in size, depth, salinity, and human impact (Conde et al., 2003). These systems are extremely shallow and connect periodically with the ocean through a channel built on a sand bar. Most of the research performed on the phytoplankton structure in the coastal lagoons of Uruguay focused on the nano and microplanktonic fractions, composed mainly by diatoms and flagellates (Conde et al., 2002; Bonilla et al., 2005), and occasionally by cyanobacterial blooms, e.g. Nodularia spumigena (Pérez et al., 1999) and Pseudoanabaena sp. (Conde et al., 2005). However, recent studies showed that the APP fraction could represent more than half of the total phytoplanktonic chlorophyll $a$.

The relative contribution of the autotrophic eukaryotic (Pe) and prokaryotic (Pcy) picoplanktonic fractions to the total phytoplankton biomass in five subtropical coastal lagoons was determined, and the relationship with selected environmental factors was analyzed. We hypothesized that (1) the relative contribution of picoplanktonic biomass has an inverse relationship with total phytoplankton biomass and (2) the relative contribution of picoplankton is higher under low nutrient availability.

\section{STUDY SITE}

Five coastal lagoons (from West to East: Laguna del Diario, Laguna de José Ignacio, Laguna Garzón, Laguna de Rocha, and Laguna de Castillos) were selected (Fig. 1). The climate of the region is subtropical (Bailey, 1998) (historical annual air temperature for $1951-1991=16.0^{\circ} \mathrm{C}$ ) with rainfall well distri- 


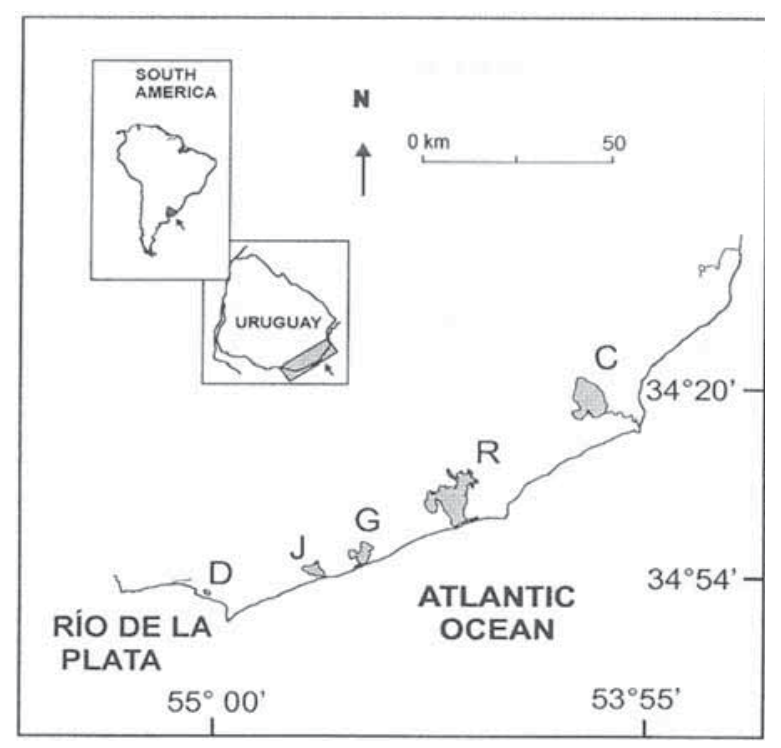

Figure 1. Location of the studied lagoons in Uruguay: D = Diario, $\mathrm{J}=$ José Ignacio, $\mathrm{G}=$ Garzón, Rocha, and C = Castillos. Localización de las lagunas estudiadas en Uruguay: $D=$ Diario, $J=$ José Ignacio, $G=$ Garzón, Rocha y $C=$ Castillos.

buted throughout the year (historical annual rainfall for $1951-1991=1105 \mathrm{~mm}$ ).

In general, size, watershed area, and depth of the lagoons increase from Diario to Castillos, while the human impact is more important in Diario. The connection with the ocean is variable between these systems. Rocha, Garzón, and J. Ignacio connect to the Atlantic Ocean through a channel on a sand bar, Castillos through a $10 \mathrm{~km}$ stream, and Diario lost its natural connection by the construction of a coastal road. As a consequence, the marine influence between systems is highly variable, with values of conductivity ranging from 0.2 to $21.4 \mathrm{mS} / \mathrm{cm}$ (Bonilla et al., 2006).

According to previous investigations in these lagoons, soluble reactive phosphorous (SRP) concentration fluctuates between 23 and $76 \mu \mathrm{g} / \mathrm{l}$, dissolved inorganic nitrogen (DIN) between 6.7 and $126 \mu \mathrm{g} / \mathrm{l}$, and the atomic ratio DIN/SRP is generally low ( $<1$ to 13 ) (Conde et al., 2005; Bonilla et al., 2005). Reactive silica (RS) is usually high $(0.6-3.5 \mathrm{mg} / \mathrm{l})$ and the total phytoplankton chlorophyll- $a$ concentration $(\mathrm{Chl}-a)$ varies from 1.3 to $14 \mu \mathrm{g} / \mathrm{l}$ (Bonilla et al., 2006).

\section{MATERIAL AND METHODS}

\section{Sampling}

In order to characterize the picoplankton contribution under different environmental situations, a seasonal sampling was performed in the five lagoons during 2005 (February $=$ summer, May = autumn, July $=$ winter, November $=$ spring). Two sampling sites were chosen in each lagoon, corresponding to limnic influenced areas (station $\mathrm{N}$, North) and marine (station S, South), except in Diario, which is a freshwater system.

\section{Abiotic variables}

During each sampling we determined in situ: water depth (Z), temperature, and dissolved oxygen (Horiba $\AA$ OM-14), photosynthetically active radiation profiles (PAR, measured every $10 \mathrm{~cm}$ with a Li-Cor $\AA 2 \pi$ collector), $\mathrm{pH}$, and

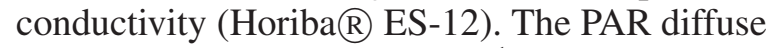
attenuation coefficient $\mathrm{K}_{d}\left(\mathrm{~m}^{-1}\right)$ was calculated following Kirk (1994).

Subsurface samples were collected for nutrient analyses; dissolved inorganic nitrogen (DIN; ammonium + nitrite + nitrate), soluble reactive phosphorus (SRP), reactive silica (RS), and suspended solids (SS) were analyzed according to APHA (1985).

\section{Phytoplankton}

Subsurface samples were collected in plastic bottles (2 1) for phytoplankton identification and quantification. Water samples were preserved in lugol for quantification of the nano and microplankton fractions in an inverted microscope at $400 \mathrm{X}$ in random fields, according to Utermöhl (1958). Samples for qualitative analyses were preserved in $\mathrm{Na}_{2} \mathrm{CO}_{3}$-neutralised formaldehyde (5\% final concentration) and were observed under a microscope at $1000 \mathrm{X}$.

APP samples were pre-filtered using a $5 \mu \mathrm{m}$ pore size net, fixed in $2 \%$ glutaraldehyde, and kept in darkness at $-80^{\circ} \mathrm{C}$ until analysis by flow cytometry. A FACS Vantage cytometer (Becton Dickinson) equipped with a 488-argon laser was used. A light-scatter (side scatter or SSC) and 
two fluorescent parameters (FL2 $=585 / 42$ and FL3 $=675 / 20$ ) were employed to discriminate photosynthetic cells by size and fluorescence properties. The FL2 signal corresponds to phycoerythrin and the FL3 to chlorophyll. Yellow-green latex Polysciences beads of 2 and $6 \mu \mathrm{m}$ diluted in phosphate buffer saline solution (PBS) were employed as reference sizes.

Chl- $a$ concentration was determined for total phytoplankton and picophytoplankton. Samples (0.3 to 11$)$ were filtered either directly onto Whatman GF/F filters (for the total fraction) or through $3 \mu \mathrm{m}$ pore size polycarbonate filters and then onto $\mathrm{GF} / \mathrm{F}$ (for the picoplankton fraction). The filters were frozen at $-20^{\circ} \mathrm{C}$ until analysis. Phytoplankton Chl- $a$ was extracted following sonication $(1.5 \mathrm{~min})$ in $5 \mathrm{ml}$ of $90 \%$ acetone and kept overnight in darkness at $4^{\circ} \mathrm{C}$. The extracts were cleared by filtration through $\mathrm{GF} / \mathrm{C}$ filters and analyzed in a Beckman UV-Vis spectrophotometer at $663 \mathrm{~nm}$ before and after acidification with $\mathrm{HCl}$ 0.12 N (Wetzel \& Likens, 1991).

\section{Data analyses}

Since data was not normally distributed both before and after simple transformations, the differences in abiotic and biotic variables between lagoons and between stations ( $\mathrm{N}$ and $\mathrm{S}$ ) were tested using the Kruskall-Wallis (K-W) nonparametric test. We performed a Kendall nonparametric correlation $(\mathrm{K}, \tau=\mathrm{Tau})$ in order to test correlations between pairs of variables. To analyze the relationship between APP and main abiotic variables we ran a multivariate ordination method, the Principal Component Analysis (PCA) (Ter Braak \& Smilauer, 1998), using forward selection method the following variables were selected: $\mathrm{K}$, $\mathrm{SS}, \mathrm{K}_{d}$, DIN/SRP and APP relative contribution to total Chl- $a(\%$ APP Chl- $a)$.

Table 1. Mean and standard deviation (between brackets) of abiotic variables in the North (N) and South (S) stations of the studied lagoons: depth $(\mathrm{Z})$, conductivity $(\mathrm{K})$, temperature $(\mathrm{T})$, soluble reactive phosphorous (SRP), dissolved inorganic nitrogen (DIN), DIN/SRP atomic ratio, reactive silica (RS), and suspended solids (SS). Codes for lagoons as in Figure 1. (nd = below the detection limit of the method, $-=$ no data). Promedio y desvío estándar (entre paréntesis) de las variables abióticas en las estaciones del Norte $(N)$ y Sur (S) de las lagunas estudiadas: profundidad $(Z)$, conductividad $(K)$, temperatura $(T)$, fósforo reactivo soluble (SRP), nitrógeno inorgánico disuelto (DIN), relación atómica DIN/SRP, súlice reactivo (SR) y sólidos en suspensión (SS). Códigos para las lagunas como en la Figura 1. (nd = debajo del límite de detección del método, $-=$ sin datos)

\begin{tabular}{|c|c|c|c|c|c|c|c|c|c|c|}
\hline & \multicolumn{2}{|c|}{ D } & \multicolumn{2}{|c|}{ JI } & \multicolumn{2}{|c|}{ G } & \multicolumn{2}{|c|}{$\mathbf{R}$} & \multicolumn{2}{|c|}{ C } \\
\hline & $\mathrm{N}$ & S & $\mathrm{N}$ & S & $\mathrm{N}$ & $\mathrm{S}$ & $\mathrm{N}$ & $\mathrm{S}$ & $\mathrm{N}$ & S \\
\hline \multirow[t]{2}{*}{$\mathbf{Z}(\mathbf{m})$} & 1.5 & 1.7 & 0.3 & 0.3 & 0.7 & 0.9 & 0.5 & 0.6 & 1.3 & 1.0 \\
\hline & $(0.1)$ & $(0.1)$ & $(0.1)$ & $(0.1)$ & (0.6) & $(0.7)$ & $(0.2)$ & $(0.3)$ & $(0.4)$ & $(0.4)$ \\
\hline \multirow[t]{2}{*}{$\mathrm{K}(\mathbf{m S} / \mathbf{c m})$} & 0.7 & 0.8 & 12.8 & 23.6 & 5.4 & 15.1 & 15.7 & 19.7 & 5.3 & 5.4 \\
\hline & $(0.4)$ & $(0.4)$ & (17.7) & (13.7) & (4.7) & (9.3) & (8.1) & (7.9) & $(4.4)$ & (5.6) \\
\hline \multirow[t]{2}{*}{$\mathbf{T}\left({ }^{\circ} \mathbf{C}\right)$} & 18.6 & 18.9 & 19.7 & 20.9 & 18.6 & 20.3 & 20.7 & 19.8 & 18.8 & 17.9 \\
\hline & $(2.9)$ & (3.3) & (2.8) & (2.8) & (2.9) & $(4.1)$ & (4.7) & $(4.5)$ & $(3.6)$ & $(4.1)$ \\
\hline \multirow[t]{2}{*}{$\operatorname{SRP}(\mu \mathrm{g} / \mathrm{l})$} & 19.0 & 19.0 & 9.5 & 14.1 & 12.4 & 12.7 & 19.2 & 14.4 & 26.4 & 26.9 \\
\hline & (21.2) & (17.8) & (7.5) & (7.5) & (11.1) & $(7.9)$ & (17.1) & $(9.0)$ & $(9.5)$ & (11.7) \\
\hline \multirow[t]{2}{*}{ DIN $(\mu \mathrm{g} / \mathrm{l})$} & 30.5 & 6.9 & 3.2 & nd & 8.7 & 13.8 & 4.7 & nd & 28.8 & 33.3 \\
\hline & $(27.2)$ & (13.8) & (1.7) & & (17.5) & (18.8) & $(4.0)$ & & $(5.4)$ & $(50.1)$ \\
\hline \multirow[t]{2}{*}{ DIN/SRP } & 18.0 & 0.7 & 1.2 & - & 13.0 & 9.3 & 0.9 & - & 1.8 & 1.9 \\
\hline & (30.8) & (1.4) & $(0.8)$ & & $(26.0)$ & (16.7) & (1.3) & & $(2.4)$ & $(2.5)$ \\
\hline \multirow[t]{2}{*}{ RS (mg/l) } & 2.1 & 2.2 & 2.9 & 1.5 & 0.3 & 1.9 & 1.6 & 0.8 & 1.8 & 1.9 \\
\hline & (1.5) & (1.5) & (1.7) & (1.7) & (1.7) & (1.4) & (1.3) & (0.4) & $(0.5)$ & (1.1) \\
\hline \multirow[t]{2}{*}{$\mathrm{SS}(\mathrm{mg} / \mathrm{l})$} & 19.2 & 12.4 & 25.4 & 14.6 & 34.1 & 52.0 & 51.3 & 19.6 & 38.1 & 40.8 \\
\hline & (12.4) & (11.1) & (6.7) & (6.7) & (14.3) & (41.9) & (40.4) & (12.7) & (36.7) & (59.9) \\
\hline
\end{tabular}




\section{RESULTS}

\section{Abiotic factors}

Water temperature varied between 15 and $25.7^{\circ} \mathrm{C}$, with a mean for all systems of $23 \pm 1.3^{\circ} \mathrm{C}$ in summer and $16.5 \pm 1^{\circ} \mathrm{C}$ in winter (Table 1). Conductivity was significantly different between the five lagoons (K-W, $\mathrm{H}=7.5, p<0.01$ ) (Table 1). Diario presented the minimum conductivity $(0.3 \mathrm{mS} / \mathrm{cm})$ (station N, May 2005) and exhibited significant differences from the rest of the lagoons $(p<0.05)$. On the other hand, J. Ignacio presented the maximum conductivity $(36.6 \mathrm{mS} / \mathrm{cm})$ at station S in February 2005. Castillos presented conductivity values significantly lower than Rocha $(\mathrm{K}-\mathrm{W}, \mathrm{H}=7.5, p<0.01)$ and $\mathrm{J}$. Ignacio $(\mathrm{K}-\mathrm{W}, \mathrm{H}$ $=4.4, p<0.05)$. The $\mathrm{pH}$ was close to neutrality in all systems $($ mean $=7.5 \pm 0.5)$ and the dissolved oxygen values indicated over-saturation during the entire study (data not shown).

DIN concentration was generally low (Table 1) and highly variable (mean $=13.5 \mu \mathrm{g} / \mathrm{l}$, range $<1-107.2 \mu \mathrm{g} / \mathrm{l}$ ), however no significant differences were found between lagoons (K$\mathrm{W}, p>0.05)$. The maximum DIN concentration was detected in Castillos $(107.2 \mu \mathrm{g} / \mathrm{l}$, station $\mathrm{S}$, November 2005). The DIN/SRP atomic ratio was generally low $($ mean $=3.3$ ), ranging from $<1$ to 52.3, and the highest values were observed in Garzón in August (52.1, station $\mathrm{N}$ and 32.4, station S). Conductivity was negatively correlated with DIN, DIN/SRP, and $\mathrm{K}_{\mathrm{d}}(\mathrm{K}$, $p<0.05)$. A positive correlation between SS and $\mathrm{K}_{\mathrm{d}}(\mathrm{K}, \tau=-0.4, p<0.001)$ was also observed.

\section{Phytoplankton}

The nano-microplanktonic fraction of the phytoplankton was composed by pennate and centric diatoms and flagellates of different groups (cryptophytes, euglenophytes, prasinophytes, and dinophytes). The most frequent genera were Cyclotella, Cylindrotheca, Paralia, Coccconeis, Rhodomonas, Cryptomonas, Eutreptiella, and Pyramimonas. In Diario, a few genera of cyanobacteria (Anabaena, Aphanothece, Pseudanabaena) were also detected.

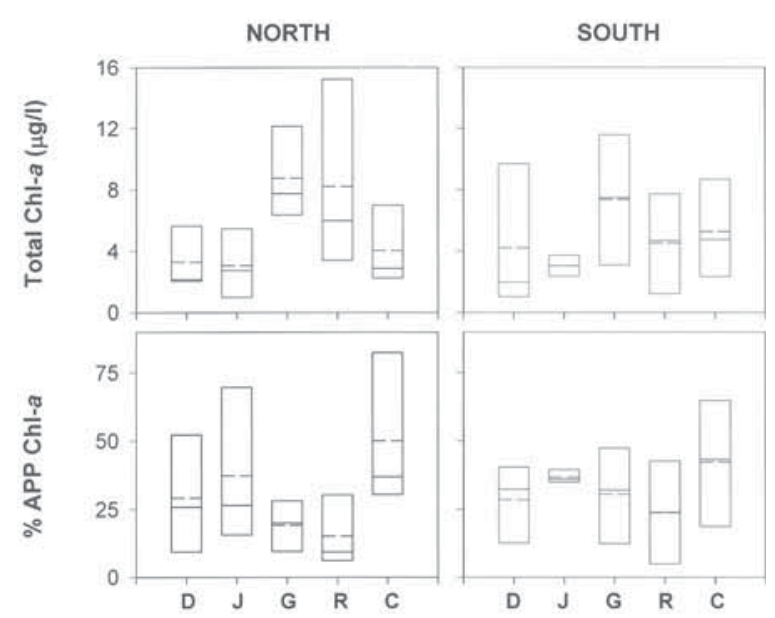

Figure 2. Box-plots of the total Chl- $a$ concentration (top) and the APP relative contribution to total Chl-a (\% APP Chl$a$, bottom) in the North (left) and South (right) stations of the studied lagoons for the entire period $($ mean $=$ dashed line, median $=$ solid line, upper boxes $=75^{\text {th }}$ percentile, lower box $=$ $25^{\text {th }}$ percentile). Codes for lagoons as in Figure 1. Gráficos de caja para la concentración de clorofila-a total (Chl-a) (arriba) y contribución relativa de Chl-a del picoplancton autótrofo (APP) a la Chl-a total (\% APP Chl-a, abajo) en las estaciones del Norte (izquierda) y Sur (derecha) de las lagunas estudiadas en todo el período (media = línea punteada, mediana = línea completa, caja de arriba= percentil 75, caja de abajo = percentil 25). Códigos para las lagunas como en la Figura 1.

The flow cytometric analysis evidenced a diverse APP composition with six ataxonomic groups. Based on fluorescence detected in FL3 and FL2, we assigned four groups as eukaryotes (G1, G2, G3 and G6) and two groups as prokaryotes (G4 and G5).

For all the lagoons during the entire study, the average abundance of the nano-microplanktonic fraction was $3425 \mathrm{cell} / \mathrm{ml}$ (range $=230-36022$ cell $/ \mathrm{ml}$ ) and 4134 cell $/ \mathrm{ml}$ for the picoplankton $($ range $=15-20716 \mathrm{cell} / \mathrm{ml})$. The biovolume of nano-microplankton for the whole study ranged between 0.03 and $6.5 \mathrm{~mm}^{3} / 1$ (mean = $\left.0.9 \mathrm{~mm}^{3} / \mathrm{l}\right)$. In Castillos, Rocha, and Garzón, the biovolume was dominated by centric and pennate diatoms (Melosira sp., Cyclotella sp., Nitzchia sp., Cylindrotheca sp.) (71.5-80.5\% of total biovolume). In J. Ignacio, cryptophytes such as Rhodomonas sp. and especially euglenophytes (Eutreptiella sp.) were frequently the dominant groups. In Diario, cryptophytes (Rhodomonas sp.), and in some cases dinoflagellates (cf. Gymnodinium sp.), were the dominant species. 


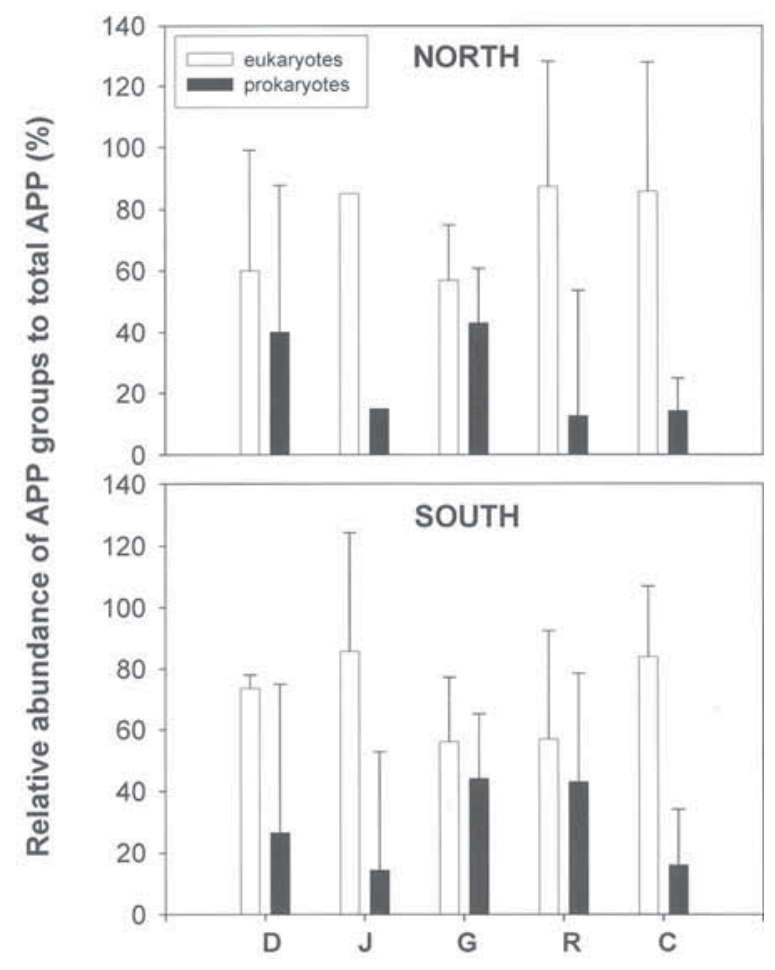

Figure 3. Relative abundance of eukaryotic (white bars) and prokaryotic (black bars) organisms to total APP (\%) determined by flow cytometry in the North (top) and South (bottom) stations of the lagoons. Codes for lagoons as in Figure 1. Abundancia relativa de organismos eucariotas (barras blancas) y procariotas (barras negras) respecto al picoplankton autótrofo $(A P P, \%)$ determinados mediante citometría de flujo en las estaciones Norte (arriba) y Sur (abajo) de las lagunas. Códigos de las lagunas como en la Figura 1.

Total Chl- $a$ varied between 0.2 and $18.7 \mu \mathrm{g} / \mathrm{l}$ (mean $=5 \mu \mathrm{g} / \mathrm{l})$ (Fig. 2). The maximum value was found in Rocha (station N, February 2005) and the minimum in J. Ignacio (station N, May 2005). Chl- $a$ was significantly different between Garzón and Diario (K-W, H $=3.9, p<0.05)$ and between Garzón and J. Ignacio (K-W, H = 7.5, $p<0.01$ ) (Fig. 2). However, no significant differences were found when stations $\mathrm{N}$ and $\mathrm{S}$ were compared between all lagoons and within each system (K-W, $p>0.05)$.

The contribution of APP to the total Chl- $a$ was highly variable, ranging from 4.2 to $96.6 \%$ (mean $=30.5 \%$ ) (Fig. 2). However, a general inverse significant correlation was found between total Chl- $a$ and \% APP Chl- $a$ (K, $\tau=0.4, p<0.001)$. The maximum \% APP Chl- $a$ was found in Castillos
(96.6 \%, station N, November 2005) and the lowest in Rocha (4.2\%, station S, August 2005). Garzón and Diario presented their maximum contribution in summer $(50.1 \%$, station $\mathrm{S}$ and $55.9 \%$, station $\mathrm{N}$, respectively), while J. Ignacio showed the maximum contribution in autumn $(81.6 \%$, station $\mathrm{N})$. As the APP contribution exhibited a high variation within lagoons, no significant differences were found between lagoons or sites (K-W, $p>0.05$ ) (Fig. 2).

The relative contribution of picoplanktonic groups to the total APP analyzed showed that Pe (G1, G2, G3, and G6) was more important than Pcy (G4 and G5) (Fig. 3). Populations of picoeukaryotes with high fluorescence detected in FL3 (G1) represented a high percentage of total picoplankton in all systems, with the highest contribution in J. Ignacio (35.2-58.7\% of total APP). The picoeukaryote group with low fluorescence in FL3 (G3) exhibited high relative abundance in all lagoons, dominating in Castillos (mean $=52.8$ and $58.5 \%$ of APP, for $\mathrm{N}$ and $\mathrm{S}$ station, respectively) and Diario (mean $=40$ and $42.5 \%$ ). However, this group presented its lowest contribution in Rocha station $\mathrm{N}$ (mean $=7.5 \%, \mathrm{~N}$ station). The group with high fluorescence in FL3 but low in FL2 (G6), tentatively assigned as cryptomonads, was present in all lagoons, with the highest contribution in Rocha (mean $=35.7$ and $42.5 \%$ for $\mathrm{N}$ and $\mathrm{S}$ station respectively).

Although Pe was the APP dominant group in most cases, the prokaryote population determined as cyanobacteria (G5) was always detected. Moreover, in some occasions, Pcy dominated the APP (99\% of the total, Garzón: February and May 2005, Diario; February 2005, and Rocha: May 2005). The groups with the lowest contribution were the picoeukaryote G2 (registered only in Garzón, mean $=2$ and $5 \%$ for $\mathrm{N}$ and $\mathrm{S}$ station, respectively) and the unknown prokaryote G4, found in Garzón, J. Ignacio and Diario (mean $=2$ and $3.5 \%$ for $\mathrm{N}$ and $\mathrm{S}$ station, respectively).

\section{APP and environmental factors}

A negative correlation between \% APP Chl- $a$ and $\mathrm{SS}(\mathrm{K}, \tau=-0.3, p<0.01)$ was found when all 


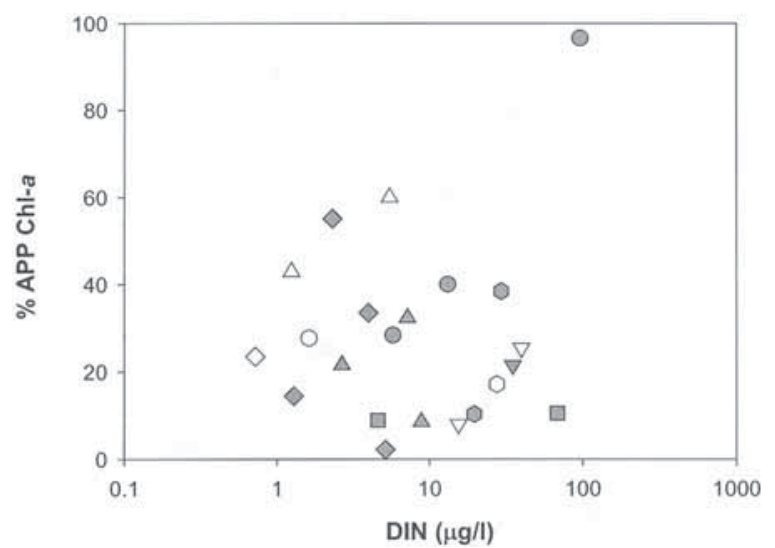

Figure 4. Relationship between APP relative Chl-a contribution to total Chl-a (\% APP Chl- $a$ ) and dissolved inorganic nitrogen concentration (DIN). Symbols for the lagoons are: squares $=$ Diario, diamonds $=$ J. Ignacio, down-triangles $=$ Garzón, uptriangles $=$ Rocha and circles $=$ Castillos. Grey symbols correspond to North stations and white ones for South stations. Relación entre la contribución relativa de Chl-a del picoplancton autótrofo (APP) a la Chl-a total (\% APP Chl-a) y la concentración de nitrógeno inorgánico disuelto (DIN). Los símbolos para la lagunas son: cuadrados $=$ Diario, diamantes $=$ J. Ignacio, triángulos hacia abajo= Garzón, triángulos hacia arriba = Rocha y círculos $=$ Castillos. Los símbolos grises corresponden a las estaciones del Norte y los blancos a las del Sur.

data were pooled and analyzed together. We also observed a negative trend between \% APP Chl- $a$ abundance and DIN concentration (K, $\tau=0.21, p=0.052$ ) (Fig. 4). However, no clear tendencies were found neither between $\%$ APP Chl- $a$ and conductivity nor between PPA and the DIN/SRP atomic ratio.

The PCA analysis performed with the main abiotic variables and \% APP Chl- $a$ contribution showed that the first two axes explained $82.9 \%$ of the total variance (Fig. 5). The first axis $(56.3 \%)$ was mainly constructed by $\mathrm{SS}$ and $\mathrm{K}_{d}$ (positive) and secondly by $\%$ APP Chl- $a$ (negative), while the second axis $(26.5 \%)$ was constructed by $\%$ APP Chl- $a$ (positive) and DIN/SRP negative. The biplot representation showed an opposite trend between APP contribution and the concentration of SS. A clear opposite trend was also found between conductivity and DIN/SRP and $\mathrm{K}_{d}$. In general, the samples were distributed randomly along the axes without clear patterns between lagoons.

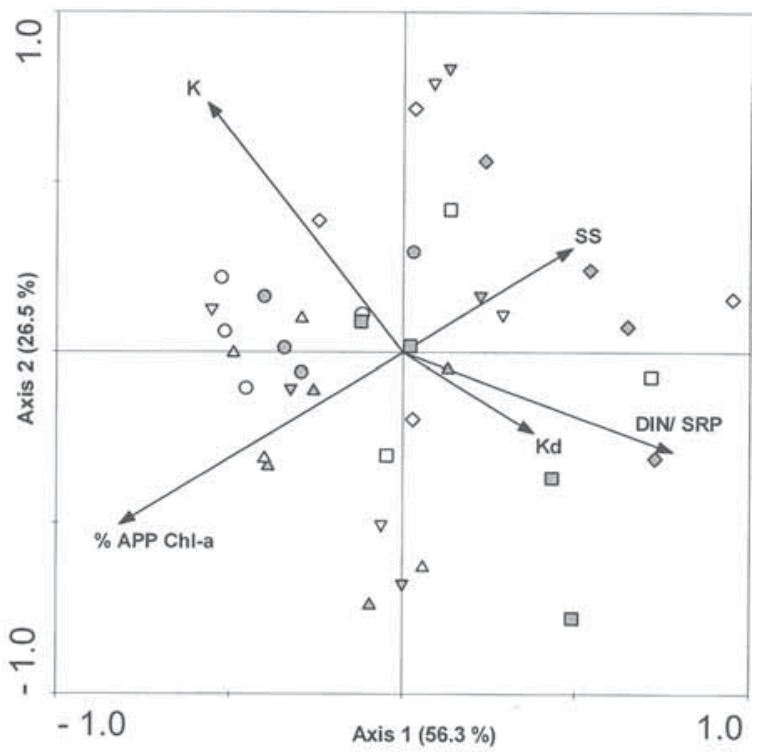

Figure 5. Results of the Principal Component Analysis (PCA) for the selected abiotic factors and APP relative Chla contribution to total Chl-a (\% APP Chl-a). The percentage of the variance explained by the PCA axes is indicated in parentheses. Symbols for lagoons as in Figure 4, and codes for variables as in Table 1 except light extinction coefficient, $\mathrm{K}_{d}$. Resultados del Análisis de Componentes Principales (ACP) para los factores abióticos seleccionados y la contribución relativa de Chl-a del picoplancton autótrofo (APP) a la Chla total (\% APP Chl-a). El porcentaje de la varianza explicada por los ejes del ACP se indica en paréntesis. Símbolos para las lagunas como en la figura 4 y códigos para las variables como en la Tabla 1 excepto el coeficiente de extinción $K_{d}$.

\section{DISCUSSION}

The relevance of the autotrophic picoplankton for aquatic food webs has intensified the investigations on these organisms. The range of coastal shallow systems analyzed in this study, including typically brackish and freshwater lagoons, represents an opportunity to address the diversity and relevance of the picoplankton fraction.

The total Chl- $a$ concentration of the lagoons was in the range previously found for some of these systems (Conde et al., 1999; Bonilla et al., 2006) and other similar lagoons of the region (Abreu et al., 1994). In our study, we found on many occasions that the APP fraction reached a high percentage of the total phytoplankton biomass. The contribution of the APP was highly 
variable (4.2 to $96.6 \%$ ), especially at low total Chl- $a$ concentrations. Phytoplankton studies in tropical systems (e.g. Lagoa Imboassica and Lagoa Cabíunas, Rio de Janeiro) showed that APP can reach contributions up to $90 \%$ of the total phytoplankton abundance (Melo \& Suzuki, 1998) and between 23 to $37 \%$ of total Chl- $a$ (Roland, 1998). Investigations in a coastal system in New Zealand revealed a significant contribution of APP to the total Chl- $a$, ranging between $40 \%$ and $80 \%$ in winter (Vincent et al., 1989) and $55 \%$ in summer (Hall \& Vincent, 1990). We also found an inverse trend between the relative importance of APP Chl$a$ and the total Chl- $a$, coinciding with observations reported elsewhere ( Chisholm, 1992; Stockner et al., 2000; Sin et al., 2000; Aubry et al., 2006).

In our study, the APP biomass contribution to total phytoplankton biomass was greater under conditions of nitrogen limitation, evidenced by the inverse trend with DIN concentration. As proposed by studies performed in other coastal systems (e.g. a river estuary transition zone, Sin et al., 2000), we also suggest that the nanomicroplankton fraction was limited by the low DIN concentrations and low DIN/SRP ratios. The traditional view for phytoplankton growth shows a limitation by nitrogen in marine systems and by phosphorus in limnic ones (Reynolds, 1984). However, some studies in both freshwater and marine systems (Klausmeier \& Litchman, 2004; Odebrecht et al., 2005; Smith, 2006) revealed multiple resource limitation by nitrogen and phosphorus simultaneously.

The species composition of the nanomicroplankton was similar to that found previously in these systems (Conde et al. 2005; Bonilla et al., 2005, 2006), composed mainly by diatoms and flagellates. Occasionally, we found some species (e.g pennate diatoms) that belong to benthic resuspended microalgae. It is well known for these shallow lagoons that wind action and sediment resuspension enhances the contribution of benthic microalgae to the water column. Studies in Laguna de Rocha demonstrated that microphytobenthos is the dominant microalgal community in terms of biomass (> $80 \%$ of the total) (Conde et al., 1999, 2003). The inverse relationship between APP biomass contribution and suspended solids and total Chl-aconcentration found in our study supports the idea that the nanoplankton is influenced by resuspended benthic algae, which in turn diminishes the relative contribution of APP.

The six APP groups differentiated by flow cytometry suggest a diverse composition of this small fraction in most of the lagoons. The high diversity of the APP has been pointed out recently for coastal systems (Díez et al., 2001; Estrada et al., 2004). The fact that the studied lagoons presented a high variability in their conductivity values suggests that the APP is integrated by species adapted to different environments, from limnic to brackish.

It has been reported that prokaryotes dominate in marine oligotrophic systems, (Partensky et al., 1999), while in more nutrient enriched coastal systems the importance of Pcy and Pe groups becomes variable (Hall \& Vincent, 1990). However, the relative importance of Pe and Pcy fractions in the picoplankton is controversial and depends on local characteristics (Murrel \& Lores, 2004). Our finding of a general dominance of Pe in the APP fraction is in good agreement with the proposed general trend for coastal brackish systems (Hall \&Vincent, 1990; Iriarte \& Purdie, 1994), but also for freshwater ones (Chrétiennot-Dinet et al., 1995). Moreover, Callieri \& Stockner (2002) showed a relationship between the APP bulk composition and the trophic state, where Pe becomes more important in enriched systems.

The results of our study suggest that nutrient availability in these subtropical brackish lagoons (with a low and highly variable DIN/SRP ratio) is an important factor that determines the size distribution of the phytoplankton community. Melo \& Suzuki (1998) suggest that salinity could determine the species composition of APP in tropical coastal lagoons, while other factors like availability of nutrients, temperature and grazing control their growth. Conversely, for a subtropical system (Lagoa dos Patos), Torgan et al. (2000) found that APP presented a high contribution in brackish areas and suggested that phytoplankton size structure is determined by a combination of salinity, availability of nutrients, and se- 
lective grazing pressure. The microzooplankton grazing pressure, not considered in this study, is another factor that could play an important role in controlling APP biomass in coastal systems.

Our results suggest that in these subtropical lagoons, the APP contribution to the total phytoplankton biomass is mainly related to the availability of nutrients, while salinity would play a key role in determining the composition of the APP community.

\section{ACKNOWLEDGEMENTS}

We thank Danilo Calliari, Anamar Britos, Erica Meerhoff, and Serrana García for field and laboratory assistance. This study was supported by grants from CSIC-I+D-UdelaR (C-O9), PDTUruguay (S/C/OP/36/09), and PEDECIBA.

\section{REFERENCES}

ABREU, P., C. ODEBRECHT \& A. GONZALEZ. 1994. Particulate and dissolved phytoplankton production of the Patos lagoon estuary, southern Brazil: comparison of methods and influencing factors. J. Plankton Res., 16: 737-735.

AMERICAN PUBLIC HEALTH ASSOCIATION. 1985. Standard Methods for the Examination of Water and Wastewater. APHA/AWWA/WPCF, Washington, 1268 pp.

AUBRY, F. B., F. ACRI, M. BASTIANINI, A. PUGNETTI \& G. SOCAL. 2006. Picophytoplankton Contribution to Phytoplankton Community Structure in the Gulf of Venice (NW Adriatic Sea). Internat. Rev. Hydrobiol., 91: 51-70.

BADYLAK, S. \& E. J. PHLIPS. 2004. Spatial and temporal patterns of phytoplankton composition in a subtropical coastal lagoon, the Indian River Lagoon, Florida, USA. J. Plankton. Res., 26: 12291247.

BAILEY, R. G. 1998. Ecoregions: The ecosystems geography of the oceans and continents, $1^{\text {st }} \mathrm{ed}$. New York: Springer-Verlag. 176 pp.

BARNES, R. S. K. 1980. Coastal lagoons. Cambridge: Cambridge University Press. 106 pp.

BEC, B., J. HUSSEIN-RATREMA, Y. COLLOS, P. SOUCHU \& A. VAQUER. 2005. Phytoplankton seasonal dynamics in a Mediterranean coastal lagoon: emphasis on the picoeukaryotic community. J. Plankton Res., 27: 881-894.

BONILLA, S., D. CONDE, L. AUBRIOT \& $\mathrm{M}^{\mathrm{a}}$ C. PÉREZ. 2005. Influence of hydrology on phytoplankton species composition and life strategies in a subtropical costal lagoon periodically connected with the Atlantic Ocean. Estuaries, 28: 884-895.

BONILLA, S., D. CONDE, L. AUBRIOT, L. RODRÍGUEZ-GALLEGO, C. PICCINI, E. MEERHOFF, L. RODRÍGUEZ-GRAÑA, P. GÓMEZ y I. MACHADO. 2006. Escalas de variabilidad ecológica y evolución ambiental de las lagunas costeras de Uruguay. In: Bases para la conservación y el manejo de la costa uruguaya. Menafra, R., L. Rodríguez-Gallego, F. Scarabino \& D. Conde (eds.): 61-630. Montevideo.

CALLIERI, C. \& J. G. STOCKNER. 2002. Freshwater autotrophic picoplankton: a review. J. Limnol., 61: 1-14.

CONDE, D., S. BONILLA, L. AUBRIOT, R. DE LEÓN \& W. PINTOS. 1999. Comparison of the areal amount of chlorophyll $a$ of planktonic and attached microalgae in a shallow coastal lagoon. Hydrobiologia, 408/409: 285-291.

CONDE, D., L. AUBRIOT, S. BONILLA \& R. SOMMARUGA. 2002. Marine intrusions in a coastal lagoon enhance the negative effect of solar UV radiation on phytoplankton photosynthetic rates. Mar. Ecol. Prog. Ser., 240: 57-70.

CONDE, D., L. RODRÍGUEZ-GALLEGO y L. RODRÍGUEZ-GRAÑA. 2003. Análisis conceptual de las interacciones abióticas y biológicas entre el océano y las lagunas de la costa atlántica de Uruguay. PNUD/GEF/RLA/99/G31 (FREPLATACiencias 8). Sección Limnología, FC/UDELAR, Montevideo, 65 pp.

CONDE, D., L. RODRÍGUEZ-GRAÑA, D. CALLIARI, P. ABREU, J. SELLANES, R. URRUTIA \& C. ODEBRECHT. 2005. Food web structure in two coastal lagoons of the Southern Atlantic Ocean: a comparative study using stable isotopes ratios. IAI SGP II Award 03SGP211-210 Final Report. Montevideo, $35 \mathrm{pp}$.

COURTIES, C., A. VAQUER, M. TROUSELLIER, J. LAUTIER, M-J. CHRÉTIENNOT-DINET, J. NEVEUX, C. MACHADO \& H. CLAUSTRE. 1994. Smallest eukaryotic organism. Nature, 370: 255.

CHISHOLM, S. W. 1992. Phytoplankton size. In: Primary productivity and biogeochemical cycles 
in the seas. P. G. Falkowski \& A. D. Woodhead (eds.): 213-237. Plenum Press, New York.

CHRÉTIENNOT-DINET, M.-J., C. COURTIES, A. VAQUER, J. NEVEUX, H. CLAUSTRE, J. LAUTIER, \& M. C. MACHADO. 1995. A new marine picoeukaryote: Ostreococcus tauri gen. et. Sp. nov. (Chlorophyta, Prasynophyceae). Phycologia, 34: 285-292.

DAY, J. W. J., C. A. S. HALL, W. M. KEMP \& A. Y. ARANCIBIA. 1989. Estuarine Ecology. New York: Wiley Interscience. $558 \mathrm{pp}$.

DÍEZ, B., C. PEDRÓS-ALIÓ \& R. MASSANA. 2001. Study of genetic diversity of eukaryotic picoplankton in different oceanic regions by smallsubunit rRNA gene cloning and sequencing. Appl. Environ. Microbiol., 67: 2932-2941.

ESTRADA, M. A., P. HENRIKSEN, J. M. A. GASOL, E. O. CASAMAYOR \& C. PEDRÓS-ALIÓ. 2004. Diversity of planktonic photoautotrophic microorganisms along a salinity gradient as depicted by microscopy, ?ow cytometry, pigment analysis and DNA-based methods. FEMS Microbiol. Ecol., 49: 281-293.

HALL, J. A. \& W. F. VINCENT. 1990. Vertical and horizontal structure on the phytoplankton communities of a coastal upwelling system. Mar. Biol., 106: 465-471.

IRIARTE, A. \& D. A. PURDIE. 1994. Size distribution of chlorophyll $a$ biomass and primary production in a temperate estuary (Southampton Water): the contribution of photosynthetic picoplankton. Mar. Ecol. Prog. Ser., 115: 283-297.

KIRK, J. T. O. 1994. Light \& photosynthesis in aquatic ecosystems. New York NY, Cambridge Univ. Press. 509 pp.

KJERVE, B. 1994. Coastal lagoons process. Elsevier Oceanography Series, 60. Amsterdam: Elsevier Science Publishers. 577 pp.

KLAUSMEIER, C. A. \& E. LITCHMAN. 2004.Phytoplankton growth and stoichiometry under multiple nutrient limitation. Limnol. Oceanogr., 49: 1463-1470.

KNOPPERS, B. 1994. Aquatic primary production. In: Costal lagoons processes. Kjerve, B. (ed.): 243286. Elsevier Oceanography Series 60, Amsterdam.

LI, W. K. W. \& P. M. DICKIE. 2001. Monitoring phytoplankton, bacterioplankton, and virioplankton in a coastal inlet (Bedford Basin) by flow cytometry. Cytometry, 44: 236-246.
MACEDO, M. F., P. DUARTE MENDES \& J. G. FERREIRA. 2001. Annual variation of environmental variables, phytoplankton species composition and photosynthetic variables in a coastal lagoon. J. Plankton Res., 23: 719-732.

MELO de S. e M. S. SUZUKI. 1998. Variaçoes temporais e espaciais do fitoplâncton das Lagoas Imboassica, Cabiúnas e Comprida. In: Ecologia das Lagoas Costeiras do Parque Nacional de Jurubatiba e do Municipio do Maçaé (RJ). Esteves F. A. (ed.): 177-203. Nucleo de Pesquisas Ecológicas de Macaé (NUPEM)-Universidad Federal do Rio de Janeiro.

MUKAI, T. 1987. Effects of surrounding physical and chemical environment on the spatial heterogeneity in phytoplankton communities of Hiroshima bay. Japan. J. Coastal Res., 3: 269-279.

MURREL, M. C. \& E. M. LORES. 2004. Phytoplankton and zooplankton seasonal dynamics in a subtropical estuary, importance of cyanobacteria. J. Plankton Res., 26: 371-382.

NOT, F., M. LATASA, D. MARIE, T. CARIOU, D. VAULOT \& N. SIMON. 2004. A single species Micromonas pusilla (Prasinophyceae), dominates the eukaryotic picoplankton in the Western English Channel. Appl. Environ. Microbiol., 70: 40644072.

ODEBRECHT, C., P. ABREU, O. O. MÖLLER JR., L. F. NIENCHESKI, L. A. PROENÇA, \& L. C. TORGAN. 2005. Drought Effects on Pelagic Properties in the Shallow and Turbid Patos Lagoon, Brazil. Estuaries, 28: 675-685.

PARTENSKY, F., J. BLANCHOT \& D. VAULOT. 1999. Differential distribution and ecology of Prochlorococcus and Synechococcus in oceanic waters: a review. In: Marine Cyanobacteria. Bulletin del Institute Océanographique de Monaco. Charpy I. \& A.W.D. Larkum (eds.): 457-475. Institute Océanographique, Monaco.

PÉREZ, M ${ }^{\text {a }}$ C., S. BONILLA, L. DE LEÓN, J. SMARDA \& J. KOMÁREK. 1999. A bloom of Nodularia baltica-spumigena group (Cyanobacteria) in a shallow coastal lagoon of Uruguay, South America. Algolog. Studies, 93: 91-101.

PETERSEN, R. 1991. Carbon-14 uptake by picoplankton and total phytoplankton in eight New Zealand lakes. Int. Revue. Ges. Hydrobiol., 76: 631-641.

REYNOLDS, C. S. 1984. The ecology of freshwater phytoplankton. Cambridge: Cambridge University Press. 384 pp. 
RODRÍGUEZ, F., E. DERELLE, L. GUILLOULE, F. GALL, D. VAULOT \& H. MOREAU. 2005. Ecotype diversity in the marine picoeukaryote $O s$ treococcus (Chlorophyta, Prasinophyceae). Environ. Microbiol., 7: 853-859.

ROLAND, F. 1998. Produçao fitoplanctônica em diferentes classes de tamanho das Lagoas Imboassica e Cabiúnas. In: Ecologia das Lagoas Costeiras do Parque da Restinga de Jurubatiba e do Municipio do Maçaé (RJ). F. A. Esteves (ed.): 159-172. Nucleo de Pesquisas Ecológicas de Macaé (NUPEM), Universidad Federal do Rio de Janeiro, Rio de Janeiro.

SIN, Y., R. L. WETZEL \& I. C. ANDERSON. 2000. Seasonal variations of size- fractioned phytoplankton along the salinity gradient in the York River estuary, Virginia (USA). J. Plankton Res., 22: 19451960.

SMITH, V. H. 2006. Responses of estuarine and coastal marine phytoplankton to nitrogen and phosphorus enrichment. Limnol. Oceanogr., 51:377-384.

STOCKNER, J. G. 1991. Autotrophic picoplankton in freshwater ecosystems: the view from the summit. Int. Rev. Ges. Hydrobiol., 76: 483-492.

STOCKNER, J. G., C. CALlIERI \& G. CRONBERG. 2000. Picoplankton and other non-bloom forming cyanobacteria in lakes. In: The Ecology of Cyanobacteria. A. Whitton and M. Potts (eds.): 195-231. Netherlands: Kluwer Academy Publishers.

SUTTLE, C. A., J. G. STOCKNER \& P. J. HARRISON. 1987. Effects of nutrient pulses on com- munity structure and cell size of a freshwater phytoplankton assemblage in culture. Can. J. Fish. Aquat. Sci., 44: 1768-1774.

SUTTLE, C. A., J. G. STOCKNER, K. S. SHOTREED \& P. J. HARRISON. 1988. Time -course studies of size- fractioned phosphate uptake: are larger cells better competitors for pulses of phosphate than smaller cells?. Oecologia, 74: 571576.

TER BRAAK, C. J. F. \& P. SMILAUER. 1998. A theory of gradient analysis. Adv. Ecol. Res., 18: 93138.

TORGAN, L. C., C. ODEBRECHT e L. F. H. NIENCHESKI. 2000. Variação espacial da estrutura de tamanho do fitoplâncton na Laguna dos Patos, Sul do Brasil. Atlantica, 22: 95-111.

UTERMÖHL, H. 1958. Zur Vervollkommung der quantitativen Phytoplankton-Methodik. Mitt int. Ver. Limnol,. 9: 1-38.

VINCENT, W. F., F. H. CHANG, A. COLE, M. T. DOWNES, M. R. JAMES, L. MAY, M. MOORE \& P. H. WOODS. 1989. Short-term changes in planktonic community structure and nitrogen transfers in a coastal upwelling system. Estuarine, Coastal and Shelf Science, 29: 131-150.

WETZEL, R. \& G. E. LIKENS. 1991. Limnological analyses. Philadephia: Saunders, 357 pp.

WORDEN, A., J. NOLAN \& B. PALENIK. 2004. Assessing the dynamics and ecology of marine picophytoplankton : the importance of the eukaryotic component. Limnol. Oceanogr., 49: 168-179. 